\title{
COW GHEE: AN ENHANCER OF PERCUTANEOUS ABSORPTION
}

\author{
M. Manoj Kumar ${ }^{1}$, Shashank Gorityala ${ }^{2}$ \\ ${ }^{1}$ Department of Pharmacology, Sir C. R. Reddy College of Pharmaceutical Sciences, Eluru, AP, India. \\ ${ }^{2}$ Department of Bioanalytical Chemistry, Covance Laboratories, Madison, WI 53704, USA. \\ *Corresponding author e-mail: manoj.maguluru@gmail.com
}

\begin{abstract}
:
Ghee, clarified butter, is the natural animal fat obtained from milk. Use of cow ghee in India is as old as Indian culture. Cow ghee does not get spoiled for longer periods as it contains no water. Cow ghee is considered as an excellent base for the preparation of Ayurvedic medicines. The ability of cow ghee to permeate into deeper tissues makes it as an ideal base for preparing Ayurvedic dosage forms. Our work is targeted to estimate the enhancement of percutaneous absorption by cow ghee using isolated goat skin as the animal membrane. Three drugs namely Salicylic acid, Diclofenac diethyl amine and Neomycin sulphate are used for the study. Salicylic acid is formulated as an ointment by replacing lipid base with cow ghee in different proportions $(5 \%, 10 \%, 15 \%, 20 \%$ and $25 \%)$. Salicylic acid ointment without cow ghee $(0 \%$ cow ghee) is used as a reference for comparison. Similarly, diclofenac diethyl amine and neomycin sulphate are formulated as creams using cow ghee in different proportions $(5 \%, 10 \%, 15 \%, 20 \%$ and $25 \%)$. The fur on the goat skin was shaved and $3 \mathrm{~g}$ of ointment/cream is applied on it. The other side of the skin is dipped in to the modified krebs buffer solution. Six such experimental setups are made for each drug i.e., one for each concentration of cow ghee $(0 \%, 5 \%, 10 \%, 15 \%, 20 \%$ and $25 \%)$. The results obtained show the definite increase in rate of absorption and also definite decrease in absorption half life with increase in concentration of cow ghee for all the three drugs. From the results obtained it is clear that cow ghee enhances the percutaneous absorption of drugs. However, further studies like accelerated stability testing are needed to estimate the stability of the dosage form. Adding appropriate preservatives is needed to improve the stability of the preparation.
\end{abstract}

Key words: Cow ghee, Percutaneous absorption, Skin absorption, Skin permeability, Permeability enhancement.

\section{INTRODUCTION:}

Ghee, clarified butter, is the natural animal fat obtained from milk. Its use in India is as old as Indian culture. Cow ghee is essential and sacred component required in hindu religious rituals called yagnyas and homas (fire offerings). In this cow ghee is offered to agni (fire). In Yagnyas agni is considered as mouth of god and through him we feed god with ghee. So cow ghee is considered as food of gods. An ancient Indian medical system, Ayurveda, utilizes ghee as a vehicle in many medicinal preparations. Ghee is the oldest known cooking oil in India. Thus, use of ghee is mixed with Indian culture through religion, medicine and kitchen. Indians consume considerable amount of ghee through their diet. Ghee is the most suitable fuel into the fires of digestion. Cow ghee cross the cell membrane and gets absorbed easily. It is also a concentrated source of energy having dietetic value, easier for digestion and absorption. Fats and fatty acids are building blocks of lipids. They are the main components in biological membranes. They offer flexibility and fluidity to cell membranes 
and also helpful in transport of substances across the membrane [1].

Among all edible fats from animal and vegetable sources cow ghee is best digested. Nearly $96 \%$ of cow ghee is digested. Most of the Ayurvedic formulations used for the treatment of ailments especially in those which are used for treatment of chronic and degenerative diseases contains cow ghee as an integral part. It is used as an agent that helps for nourishment, extraction, absorption and assimilation.

The pure form of cow ghee is light, oily and do not contain water, lactose and other milk solids. Cow ghee does not get spoiled for longer periods as it contains no water. So refrigeration is not needed for its preservation. According to Ayurveda as ghee becomes older for years its taste may become slightly bitter but its effectiveness and healing properties increases. In many classical Ayurvedic formulations 5 to 10 year old ghee is highly preferred.

Cow ghee is an excellent base for the preparation of Ayurvedic medicines. The ability of cow ghee to permeate into deeper tissues makes it as an ideal base for preparing Ayurvedic dosage forms. Ayurveda described cow ghee as good adjuvant/vehicle for transport of drugs into the deeper areas in the tissue layers of the human body. Human cell membranes contain lipids and cow ghee shows highly lipophilic action. This facilitates the drug to get placed at target cellular level by cow ghee. Cow ghee digests, absorbs and delivers the drug at the target. This is the most crucial thing to take place for getting maximum benefit from the formulation used in therapy.

Ghee cools the body and prevents overheat. Ghee makes internal body organs smooth and soft and also increases secretion of internal juices, which are diminished by aging. Ghee improves intelligence and intellect. It also acts as a lubricant over the walls of GIT and facilitates easy egestion. Ghee is also better in wound healing. Ghee can be used as bath oil and also as moisturizer [2]. Cow ghee is useful as an antidote [3]. Cow ghee is useful in enhancement of memory. It possesses nootropic activity. Medicated ghee, Pancha Gavya Gritha (PGG), is superior to plain cow ghee [4]. Optimum use of ghee does not result in CAD. The previous studies involving animal models revealed the dose dependent decrease of Cholesterol levels. That includes HDL, LDL, VLDL, and triglyceride levels. Even $10 \%$ ghee in diet did not show any evidence for increased risk of CAD [5][6]. Interestingly a study conducted in the men of rural India has shown the decreased or lesser prevalence of CAD in the men who consume high amount of ghee [7].

Cow ghee contains fat soluble vitamin $\mathrm{E}$ and beta carotene which are antioxidants. Panchagavya ghrita is a peculiar combination of five cow products namely dung, urine, milk, curd and ghee [8]. It contains both water soluble and fat soluble antioxidants and acts strong antioxidant and relieves oxidative stress [9]. Panchagavya ghrita can also be used in the treatment of vishamajvara ( Malaria/Typhoid) [10], psychogenic and neurogenic disorders [11]. According to ayurveda ghee enhances percutaneous absorption of substances. Being more lipophilic and possessing lubricating property ghee aids for better diffusion and percutaneous absorption of drugs and other substances which are topically applied [12].

Skin is the largest organ of the body. It covers $1.6 \mathrm{~m}^{2}$ surface area and accounts for $16 \%$ of total body weight of an adult approximately [13]. It is a multilayered outer covering of the body and protects all the internal body organs from environmental risk factors. The role of skin is major in offering protection against invading pathogenic species. Skin 
serves as insulation and acts as thermoregulator. It also prevents loss of water from the body. It is a sensory organ and provides the sense of touch.

Skin absorption is a route by which substance can enter the body through the skin. Permeability is the term that refers the process which allows the movement of substances across the biological barriers. Human skin shows high selectivity and low permeability. This property of the skin prevents the entry of foreign particles and microorganisms into the body there by it protect the body invading microorganisms and toxins. Stratum corneum, the outer most layer of the skin performs this function effectively. However, sometimes it is desired to permit the penetration of substances into deeper layers of the skin and even into muscular layers. Inunction is a process of rubbing the medicament against the skin to show systemic action. Some pain killers are rubbed against the skin to relieve deep muscular pains. In such cases drug shows property of penetration and diffusion in to the deeper layers of the skin and even in to the muscular layers. In such cases to facilitate easy penetration of drug molecules, permeation of the skin is to be enhanced. Electroporation, Iontophoresis, Sonophoresis, magnetophoresis, and Microporation are some physical methods used for the enhancement of skin permeation. Along with these physical methods chemical permeation enhancers can also be used [14]. In topically applied dosage forms usually chemical permeation enhancers are used. This alters the barrier property of stratum corneum and facilitates the process of absorption by enhancing the penetration [15]. The chemical agents used as permeation enhancers may produce the desired effect by various mechanisms. They include the interaction of permeability enhancer with the organizational lipids of the skin and resulting in increase in fluidity [16], interaction with intercellular protein and keratin denaturation [17], extraction of lipids from stratum corneum causing the displacement of bound water and loss of horny cells also delamination of stratum corneum [18], enhancement of solubility and increasing partitioning into stratum corneum [19].

Our work is targeted to estimate the enhancement of percutaneous absorption of drugs by cow ghee using isolated goat skin as the animal membrane.

\section{METHOD}

In 2007 Cetin Tas and etal described a method of studying percutaneous absorption using rat skin as an In vitro animal model. They used de-fibered wistar strain rat skin to study percutaneous absorption [20]. In 2016 Eman Abd and etal described various models for study of percutaneous absorption of drugs. Model of human skin is also one among them. They also mentioned pig skin as a most nearer alternative to human skin [21]. However, for preliminary estimation any mammalian skin can be used. So, we used defibered goat skin was used for estimation percutaneous absorption of drugs. We bought freshly excised skin of a goat and removed the hair from the skin using electric hair remover carefully. After careful removal of adhering fat the skin is soaked in saline solution for half an hour before using for percutaneous absorption study.

Ointments and creams with $0 \%$ were prepared using Pharmacopoeial procedures. Later some amount of lipid used in procedure is replaced by cow ghee and prepared ointments creams of respective drugs with $5 \%, 10 \%, 15 \%, 20 \%, 25 \%$ cow ghee concentrations. They were used in the study. 


\section{RESULTS}

The above results show that the increase in concentration of cow ghee increased the rate of absorption of salicylic acid. Absorption halflife $(\mathrm{t} 1 / 2)$ decreased considerably with increase in concentration of cow ghee in formulation.

\begin{tabular}{|r|r|r|r|}
\hline $\begin{array}{l}\text { \% of } \\
\text { Cow } \\
\text { Ghee }\end{array}$ & $\begin{array}{c}\text { Salicylic } \\
\text { acid }\end{array}$ & Diclofenac & Neomycin \\
\hline 0 & 0.002014 & 0.002581 & 0.003406 \\
\hline 5 & 0.002418 & 0.003283 & 0.003607 \\
\hline 10 & 0.003008 & 0.004924 & 0.003756 \\
\hline 15 & 0.003912 & 0.00627 & 0.004316 \\
\hline 20 & 0.00544 & 0.008237 & 0.00595 \\
\hline 25 & 0.006361 & 0.01027 & 0.009631 \\
\hline
\end{tabular}

The above results show that the increase in concentration of cow ghee increased the rate of absorption of Diclofenac diethyl amine. Absorption half life $(\mathrm{t} 1 / 2)$ of Diclofenac diethyl amine decreased considerably with increase in concentration of cow ghee in formulation.

\begin{tabular}{|c|c|c|c|}
\hline $\begin{array}{c}\text { \% of } \\
\text { Cow } \\
\text { Ghee }\end{array}$ & $\begin{array}{c}\text { Salicylic } \\
\text { acid }\end{array}$ & Diclofenac & Neomycin \\
\hline 0 & 344 & 268 & 203 \\
\hline 5 & 287 & 211 & 192 \\
\hline 10 & 230 & 141 & 185 \\
\hline 15 & 177 & 111 & 161 \\
\hline 20 & 127 & 84 & 116 \\
\hline 25 & 109 & 67 & 72 \\
\hline
\end{tabular}

The above results show that the increase in concentration of cow ghee increased the rate of absorption of Neomycin Sulphate. Absorption half life (t1/2) of Neomycin Sulphate decreased considerably with increase in concentration of cow ghee in formulation. All the above obtained results show increase in percutaneous absorption of drugs when cow ghee is incorporated in their formulation. Increase in concentration of cow ghee resulted in increase absorption in all the three drugs.

ANOVA was applied on the value of $\mathrm{Ka}$ and t1/2 values of drugs against different concentrations of cow ghee to know whether the obtained values are significant or not. In this, the data is grouped depending on the concentration of cow ghee used in formulation.

From the results of Anova, it is observed that $p$ value is less than alpha value $(0.005)$ and ' $F$ value' is greater than that of ' $F$ critical value' or 'F-statistic'. So, null hypothesis was rejected. The values were considered to have significance.

\section{DISCUSSION}

From the observed results of the work increase in concentrations cow ghee in ointments and creams had resulted in increase in percutaneous absorption. Though all the ointments and creams contain lipids as base more than them cow had shown increase in absorption across the layers of skin. This may be due to increase in fluidity of

\begin{tabular}{|l}
\begin{tabular}{|l|c|c|c|c|c|c|}
\hline \multicolumn{1}{|l|}{ ANOVA : Single Factor on Ka of Drugs } \\
\hline Between Groups & $S S$ & $d f$ & $M S$ & $F$ & $P$-value & $F$ crit \\
\hline Within Groups & $8.02 \mathrm{E}-05$ & 5 & $1.6 \mathrm{E}-05$ & 9.627347 & 0.000699 & 3.105875 \\
\hline Total & $2 \mathrm{E}-05$ & 12 & $1.67 \mathrm{E}-06$ & & & \\
\hline ANOVA: Single Factor on $\mathrm{t}_{1 / 2}$ of Drugs & 0.0001 & 17 & & & & \\
\hline Source of Variation & $S S$ & $d f$ & $M S$ & $F$ & $P$-value & $F$ crit \\
\hline Between Groups & 77763.61 & 5 & 15552.72 & 7.976891 & 0.001612 & 3.105875 \\
\hline Within Groups & 23396.67 & 12 & 1949.722 & & & \\
\hline Total & 101160.3 & 17 & & & & \\
\hline
\end{tabular}
\end{tabular}


membranes across the layers of skin. As a whole, we can conclude that more than commercially used lipids of ointments and creams cow ghee produce better absorption of the drugs across the skin. However, further studies are to be carried out to assess its stability in formulation and it is necessary to find out a suitable preserve to improve the stability of the formulation. As we used goat skin as the model to study percutaneous absorption of drugs in presence of cow ghee, it is also necessary to verify whether the results pattern is same in human models or not.

\section{ACKNOWLEDGEMENT}

Authors are thankful to the Principal, Sir C. R. Reddy College of Pharmaceutical Sciences, Eluru, West Godavari, Andhra Pradesh, India for providing necessary facilities and actions towards the fruitful completion of this research work.

\section{CONFLICT OF INTEREST}

The author(s) confirm that this article content has no conflict of interest.

\section{REFERENCES}

[1] Ankita Mahakalkar, Pranita Kashyap, Ram Bawankar1 \& Bhushan Hatwar. The Versatility of Cow Ghee- An Ayurveda Perspective. American Journal of Drug Delivery and Therapeutics. 2014,1:1, 028-034.

[2] D. M. Biyani, Dr. P. R. P. Verma, Dr. A.K. Dorle, Mr. V. Boxey. A Case Report on Wound Healing Activity of Cow Ghee. International Journal of Ayurvedic Medicine, 2011, 2(3), 115118.

[3] Dr.Dilip Kumar Goswami, Dr. Rama Kanta Sharma. GHEE AS AN ANTIDOTE: A LITERARY REVIEW. International Ayurvedic medical
Journal July- 2016. Volume 4; Issue $07 ; 1317-1323$.

[4] Pandey A., Pawar M.S. Assessment of Nootropic Activity of Panchagavya Ghrita in Animal Models. International Journal of Scientific and Research Publications August 2015, Volume 5, Issue 8, 1 - 5.

[5] Hari Sharma, Xiaoying Zhang1, Chandradhar Dwivedi.The effect of ghee (clarified butter) on serum lipid levels and microsomal lipid peroxidation. AYU Apr - Jun 2010. Volume 31, Issue 2. $134-140$.

[6] A.Manohar Reddy, V.Satish, M.Nagamounica, M.Manoj Kumar. Myths and Facts about Consumption of Ghee In Relation To Heart Problems - A Comparative Research Study. International Journal of Pharmacy and Pharmaceutical Sciences 2013. Vol 5, Suppl 2. 560 563.

[7] Gupta R, Prakash H. Association of dietary ghee intake with coronary heart disease and risk factor prevalence in rural males. J Indian Med Assoc 1997; 95(3): 67-69, 83.

[8] Vrddha Vagbhatta: Ashtangasangraha with Shashilekha Sanskrit commentary by Indu, edited by Shivprasad Sharma, Chi. 2/58-60. Chaukhamba Sanskrit Series office, Varanasi, First Edition 2006.

[9] Arun Athavale, Nikhil Jirankalgikar, Pankaj Nariya and Subrata De. Evaluation of In-Vitro Antioxidant Activity of Panchagavya: A Traditional Ayurvedic Preparation. International Journal of Pharmaceutical Sciences and Research, 2012. Vol. 3, Issue 8. 2543-2549. 

doi.org/10.38111/ijapb.20160203002

[10] Charak: Charaksamhita with Ayurveda Dipika commentary of Chakrapani Dutta, edited by Jadavji Trikmaji Acharya, Chi.3/304. Krishnadas Academy, Varanasi, 2000 (reprint).

[11] Ayurvedic Formulary of India, Part I. Controller of Publications, Govt. of India, New Delhi, First edition 1978.

[12] Jain Manu S. Lohare Ganesh B., Bari Manoj M.,Chavan Randhir B., Barhate S. D. Permeation studies of Diclofenac sodium from buffalo ghee as an oleaginous base. Scholars Research Library 2011. 3: 5. 244-248.

[13] Hiroshi Shimizu. Shimizu's Textbook of Dermatology chapter 1 Structure and Functions of Skin. Department of Dermatology, Faculty of Medicine and Graduate School of Medicine. Hhokkaido Univertsity.

[14] Bharkatiya $M$ and Nema RK. Skin Permeation Enhancement Techniques. J Young Pharm. 2009;1(2):110-115.

[15] Michael Goodman and Brian W. Barry. Lipid-protein-partitioning (LPP) theory of skin enhancer activity: finite dose technique. International Journal of Pharmaceutics, 57:1 (1989) 29-40.

[16] Smith SW, Anderson BD. Human skin permeability enhancement by boric acid under equilibrium aqueous conditions. J Pharm Sci 1995;84:5516.
[17]

Naik A, Potts RO, Guy RH. Mechanism of oleic acid-induced skin penetration enhancement in humans. J Cont Rel 1995;37(3):299-306.

[18] Barry BW. Novel mechanism and devices to enable successful transdermal drug delivery. Eur J Pharm Sci 2001;14:101-14.

[19] Finnin BC, Morgan TM. Transdermal penetration enhancers, applications, limitations and potential. J Pharm Sci 1999;88:955-8.

[20] Cetin Tas, Yalcin Ozkan, Alper Okyar \& Ayhan Savaser. In Vitro and Ex Vivo Permeation Studies of Etodolac from Hydrophilic Gels and Effect of Terpenes as Enhancers. Drug Delivery, 2007, 14:453-459.

[21] Eman Abd, Shereen A Yousef, Michael N Pastore, Krishna Telaprolu, Yousuf H Mohammed, Sarika Namjoshi, Jeffrey E Grice, and Michael S Roberts. Skin models for the testing of transdermal drugs. Clinical Pharmacology: Advances and Applications (2016), Volume 8, 163176.

\section{How to cite this article:}

Manoj Kumar M. Cow Ghee: An Enhancer of Percutaneous Absorption. Int. J. Adv. Pharm.Biotech., 2016; 2(3): 7-15. 
Table:

\begin{tabular}{|c|c|c|c|c|c|c|c|c|c|}
\hline \multirow{2}{*}{$\begin{array}{l}\text { Time in } \\
\text { minutes }\end{array}$} & \multicolumn{3}{|c|}{$\begin{array}{l}\text { Release kinetics of Salicylic } \\
\text { acid in } 0 \% \text { ghee ointment }\end{array}$} & \multicolumn{3}{|c|}{$\begin{array}{l}\text { Release kinetics of Salicylic } \\
\text { acid in } 5 \% \text { ghee ointment }\end{array}$} & \multicolumn{3}{|c|}{\begin{tabular}{|c|} 
Release kinetics of \\
Salicylic acid in $10 \%$ ghee \\
ointment
\end{tabular}} \\
\hline & ADA in $\mu \mathrm{g}$ & $\begin{array}{c}\text { ARA in } \\
\mu \mathrm{g}\end{array}$ & $\log$ ARA & $\begin{array}{c}\text { ADA in } \\
\mu \mathrm{g}\end{array}$ & $\begin{array}{c}\text { ARA in } \\
\mu \mathrm{g}\end{array}$ & $\log$ ARA & $\begin{array}{c}\text { ADA in } \\
\mu \mathrm{g}\end{array}$ & $\begin{array}{c}\text { ARA in } \\
\mu \mathrm{g}\end{array}$ & $\log$ ARA \\
\hline 0 & 0 & 60 & 1.778 & 0 & 60 & 1.778 & 0 & 60 & 1.778 \\
\hline 15 & 2.676 & 57.324 & 1.758 & 3.747 & 56.253 & 1.75 & 3.695 & 56.305 & 1.75 \\
\hline 30 & 3.73 & 56.27 & 1.750 & 5.297 & 54.703 & 1.738 & 5.899 & 54.101 & 1.733 \\
\hline 45 & 5.834 & 54.166 & 1.734 & 6.95 & 53.05 & 1.725 & 7.418 & 52.582 & 1.721 \\
\hline 60 & 8.44 & 51.56 & 1.712 & 8.214 & 51.786 & 1.714 & 10.446 & 49.554 & 1.695 \\
\hline 75 & 9.454 & 50.546 & 1.704 & 10.069 & 49.931 & 1.698 & 12.392 & 47.608 & 678 \\
\hline 90 & 10.973 & 49.027 & 1.690 & 12.365 & 47.635 & 1.678 & 14.879 & 45.121 & 1.654 \\
\hline 105 & 12.256 & 47.744 & 1.679 & 14.523 & 45.477 & 1.658 & 17.453 & 42.547 & 629 \\
\hline 120 & 13.854 & 46.146 & 1.664 & 16.806 & 43 & 1.635 & 19.257 & 40.743 & 610 \\
\hline 135 & 15.567 & 44.433 & 1.648 & 18.957 & 41.043 & 1.613 & 21.387 & 38.613 & 587 \\
\hline 150 & 17.026 & 42.974 & 1.633 & 20.425 & 39.575 & 1.597 & 23.426 & 36.574 & 63 \\
\hline 165 & 18.064 & 41.936 & 1.623 & 06 & 494 & 1.585 & 25.163 & 34.837 & 42 \\
\hline 180 & 19.454 & 40.546 & 1.608 & 22.489 & 37.511 & 1.574 & 26.746 & 33.254 & 1.522 \\
\hline 195 & 20.552 & 39.448 & 1.596 & 23.354 & 36.646 & 1.564 & 27.627 & 32.373 & 1.51 \\
\hline 210 & 21.126 & 38.874 & 1.59 & 32 & 35.668 & 1.552 & 28.549 & 31.451 & 1.497 \\
\hline 225 & 22.076 & 37.924 & 1.579 & 25.126 & 34.874 & 1.542 & 29.326 & 30.674 & 1.487 \\
\hline 240 & 22.756 & 37.244 & 1.571 & 25.989 & 34.011 & 1.531 & 29.965 & 30.035 & 1.478 \\
\hline $\mathrm{t}_{1 / 2}$ & \multicolumn{3}{|c|}{$343.609 \mathrm{~min}$ or $5.727 \mathrm{hr}$} & \multicolumn{3}{|c|}{$286.649 \mathrm{~min}$ or $4.777 \mathrm{hr}$} & \multicolumn{3}{|c|}{$230.184 \mathrm{~min}$ or $3.836 \mathrm{hr}$} \\
\hline $\begin{array}{l}\text { Time in } \\
\text { minutes }\end{array}$ & \multicolumn{6}{|c|}{$\begin{array}{l}\text { Release kinetics of Salicylic Release kinetics of Salicylic } \\
\text { acid in } 15 \% \text { ghee ointment acid in } 20 \% \text { ghee ointment }\end{array}$} & & & \\
\hline 0 & 0 & 60 & 1.778 & 0 & 60 & 1.778 & 0 & 60 & 1.778 \\
\hline 15 & 4.122 & 55.878 & 1.747 & 5.223 & 54.777 & 1.739 & 5.962 & 54.038 & 1.733 \\
\hline 30 & 5.564 & 54.436 & 1.736 & 6.436 & 53.564 & 1.729 & 6.899 & 53.101 & 1.725 \\
\hline 45 & 7.176 & 52.824 & 1.723 & 8.89 & 51.11 & 1.708 & 9.754 & 50.246 & 1.701 \\
\hline 60 & 8.96 & 51.04 & 1.708 & 11.965 & 48.035 & 1.6816 & 12.516 & 47.484 & 1.676 \\
\hline 75 & 11.912 & 48.088 & & 15.079 & 44.921 & 1.652 & 16.189 & 43.811 & 542 \\
\hline 90 & 14.397 & 45.603 & 1.659 & 19.843 & 40.157 & 1.604 & 20.663 & 39.337 & 1.595 \\
\hline 105 & 17.523 & 42.477 & 1.628 & 23.121 & 36.879 & 1.567 & 24.236 & 35.764 & 1.553 \\
\hline 120 & 20.611 & 39.389 & 1.595 & 27.046 & 32.954 & 1.518 & 28.343 & 31.657 & 1.5 \\
\hline 135 & 24.76 & 35.24 & 1.547 & 31.108 & 28.892 & 1.461 & 32.545 & 27.455 & 1.439 \\
\hline 150 & 26.46 & 33.54 & 1.526 & 33.768 & 26.232 & 1.419 & 34.826 & 25.174 & 1.401 \\
\hline 165 & 28.723 & 31.277 & 1.495 & 35.528 & 24.472 & 1.389 & 37.023 & 22.977 & 1.361 \\
\hline 180 & 30.523 & 29.477 & 1.469 & 37.429 & 22.571 & 1.353 & 39.472 & 20.528 & 1.312 \\
\hline 195 & 31.894 & 28.106 & 1.449 & 39.106 & 20.894 & 1.320 & 41.336 & 18.664 & 1.271 \\
\hline 210 & 33.114 & 26.886 & 1.429 & 40.118 & 19.882 & 1.298 & 43.874 & 16.126 & 1.207 \\
\hline 225 & 34.065 & 25.935 & 1.414 & 41.077 & 18.923 & 1.277 & 44.827 & 15.173 & 1.181 \\
\hline 240 & 34.989 & 25.011 & 1.398 & 41.957 & 18.043 & 1.256 & 45.684 & 14.316 & 1.156 \\
\hline$t_{1 / 2}$ & \multicolumn{3}{|c|}{$177.174 \mathrm{~min}$ or $2.95 \mathrm{hr}$} & \multicolumn{3}{|c|}{$127.472 \mathrm{~min}$ or $2.124 \mathrm{hr}$} & \multicolumn{3}{|c|}{$108.967 \mathrm{~min}$ or $1.816 \mathrm{hr}$} \\
\hline
\end{tabular}




\begin{tabular}{|c|c|c|c|c|c|c|c|c|c|}
\hline \multicolumn{10}{|c|}{ Table: } \\
\hline \multirow{2}{*}{$\begin{array}{l}\text { Time } \\
\text { in } \\
\text { minutes }\end{array}$} & \multicolumn{3}{|c|}{\begin{tabular}{|c|} 
Release kinetics of \\
Diclofenac diethyl Amine \\
in $15 \%$ ghee cream
\end{tabular}} & \multicolumn{3}{|c|}{\begin{tabular}{|c|} 
Release kinetics of \\
Diclofenac diethyl Amine in \\
$20 \%$ ghee cream
\end{tabular}} & \multicolumn{3}{|c|}{\begin{tabular}{|c} 
Release kinetics of \\
Diclofenac diethyl Amine in \\
$25 \%$ ghee cream
\end{tabular}} \\
\hline & $\begin{array}{c}\text { ADA in } \\
\mu \mathrm{g}\end{array}$ & $\begin{array}{c}\text { ARA in } \\
\mu \mathrm{g}\end{array}$ & $\begin{array}{c}\text { log } \\
\text { ARA }\end{array}$ & ADA in $\mu \mathrm{g}$ & $\begin{array}{c}\text { ARA in } \\
\mu \mathrm{g}\end{array}$ & $\begin{array}{c}\log \\
\text { ARA }\end{array}$ & ADA & ARA & $\begin{array}{c}\log \\
\text { ARA }\end{array}$ \\
\hline 0 & 0 & 5000 & 3.698 & 0 & 5000 & 3.698 & 0 & 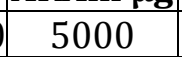 & 3.698 \\
\hline 15 & 48.21 & 79 & 7 & 09 & & & 36 & & 57 \\
\hline 30 & 676.34 & & 3.635 & 783.48 & & & & & 3.612 \\
\hline 45 & & & 3.6 & 48 & & & & & .562 \\
\hline 60 & & & 3.564 & & & & & & .513 \\
\hline 75 & & & 3.538 & & & 97 & & & 3.461 \\
\hline 90 & & & 5 & & & & & & 3.406 \\
\hline 105 & & & 3.444 & 28 & 25 & 04 & 27 & & 3.347 \\
\hline 120 & & & 3.402 & 8.84 & & & & & 3.281 \\
\hline 13 & & & 3.36 & 00 & & & & & 3.209 \\
\hline 150 & & & 3.318 & 41.07 & 175 & 3.245 & & & 3.147 \\
\hline 165 & & & 3.277 & 3468.75 & & 3.185 & & & 3.077 \\
\hline 180 & 5 & 17 & 3.236 & 34 & 13 & 3.121 & 158 & 98 & 2.995 \\
\hline 195 & 3421.87 & 1578.13 & 3.198 & 3870.53 & 1129.47 & 3.052 & 4191.963 & $80 \varepsilon$ & 2.907 \\
\hline 210 & 3549.1 & 1450.9 & 3.161 & 4044.64 & 955.36 & 2.98 & 4345.98 & 654.02 & 2.815 \\
\hline 225 & 3790.18 & 1209.82 & 3.082 & 4191.963 & 808.037 & 2.907 & 4473.213 & 526.787 & 2.721 \\
\hline 240 & 3877.23 & 1122.77 & 3.05 & 4305.803 & 694.197 & 2.841 & 4587.05 & 412.95 & 2.615 \\
\hline $\mathrm{t} 1 / 2$ & 10.6269 & $\min$ Or 1 & & $4.1365 \mathrm{mi}$ & $\mathrm{r} 1.4$ & & $.5 \min 0$ & $19-1$ & \\
\hline
\end{tabular}




\begin{tabular}{|c|c|c|c|c|c|c|c|c|c|}
\hline \multicolumn{10}{|c|}{ Table: } \\
\hline \multirow{2}{*}{$\begin{array}{c}\text { Time } \\
\text { in } \\
\text { minutes }\end{array}$} & \multicolumn{3}{|c|}{$\begin{array}{c}\text { Release kinetics of } \\
\text { neomycin in } 0 \% \text { ghee } \\
\text { cream }\end{array}$} & \multicolumn{3}{|c|}{$\begin{array}{c}\text { Release kinetics of } \\
\text { neomycin in } 5 \% \text { ghee } \\
\text { cream }\end{array}$} & \multicolumn{3}{|c|}{$\begin{array}{c}\text { Release kinetics of } \\
\text { neomycin in } 10 \% \text { ghee } \\
\text { cream }\end{array}$} \\
\hline & $\begin{array}{l}\text { ADA } \\
\text { in } \mu \mathrm{g}\end{array}$ & $\begin{array}{l}\text { ARA } \\
\text { in } \mu \mathrm{g}\end{array}$ & $\begin{array}{c}\text { log } \\
\text { ARA }\end{array}$ & $\begin{array}{l}\text { ADA } \\
\text { in } \mu \mathrm{g}\end{array}$ & $\begin{array}{l}\text { ARA } \\
\text { in } \mu \mathrm{g}\end{array}$ & $\begin{array}{c}\text { log } \\
\text { ARA }\end{array}$ & $\begin{array}{l}\text { ADA } \\
\text { in } \mu \mathrm{g}\end{array}$ & $\begin{array}{l}\text { ARA } \\
\text { in } \mu \mathrm{g}\end{array}$ & $\begin{array}{c}\text { log } \\
\text { ARA }\end{array}$ \\
\hline 0 & 0 & 5000 & 3.698 & 0 & 5000 & 3.698 & 0 & 5000 & 3.698 \\
\hline 15 & 107 & 4893 & 3.689 & 383.75 & 4616.25 & 3.66 & 464 & 4536 & 3.656 \\
\hline 30 & 635.03 & 4364.97 & 3.639 & 763.11 & 4236.89 & 3.62 & 844.56 & 4155.44 & 3.618 \\
\hline 45 & 886.64 & 4113.36 & 3.614 & 1013.21 & 3986.79 & 3.6 & 1104.39 & 3895.61 & 3.59 \\
\hline 60 & 1129.25 & 3870.75 & 3.587 & 1259 & 3740.02 & 3.57 & 1348.79 & 365 & 3.562 \\
\hline 75 & 1358.88 & 3641.12 & 3.561 & 1491 & 3508.42 & 3.54 & 1579.56 & & 3.534 \\
\hline 90 & 1533.59 & 3466.41 & 3.539 & 1671.91 & 3328.09 & 3.52 & 1758.72 & & 3.51 \\
\hline 105 & 23 & & & 1853 & 3146.66 & 3.49 & 1939 & & 3.485 \\
\hline 120 & 1928.3 & 3071.7 & 3.487 & 2062.04 & 2937.96 & 3.46 & 2158.35 & 28 & 3.453 \\
\hline 135 & 2057.72 & 2942.28 & 3.468 & 2201.78 & 2798.22 & 3.44 & 2290.23 & 2709.77 & 3.432 \\
\hline 150 & & 282 & 3.451 & & & 3.42 & & & 3.414 \\
\hline${ }^{\prime} 165$ & 2302.21 & $269^{\prime}$ & 3.431 & 2440.97 & 255 & 3.4 & & & 3.39 \\
\hline 180 & 2399.23 & 2600.77 & 3.415 & 2549.23 & 2450.77 & 3.38 & 2638.91 & 23 & 3.373 \\
\hline 195 & 250 & 249 & 3.396 & 2649 & $23 !$ & 3.37 & & & 3.352 \\
\hline 210 & 2606.31 & 239 & 3.379 & 2750.68 & 224 & 3.35 & 2849.96 & & 3.332 \\
\hline 225 & 2697.31 & 2302.69 & 3.362 & 2843.69 & 215 & 3.33 & 2943.34 & 205 & 3.313 \\
\hline 240 & 2788.89 & 221 & 3.344 & 2945.72 & 2054.28 & 3.31 & 3046.54 & 1953.46 & 3.29 \\
\hline$t_{1 / 2}$ & \multicolumn{3}{|c|}{$203.46 \mathrm{~min}$ Or $3.39 \mathrm{hr}$} & \multicolumn{3}{|c|}{$193.44 \mathrm{~min}$ Or $3.20 \mathrm{hr}$} & \multicolumn{3}{|c|}{$185.26 \mathrm{~min}$ Or $3.08 \mathrm{hr}$} \\
\hline $\begin{array}{c}\text { Time } \\
\text { in } \\
\text { minutes }\end{array}$ & \multicolumn{3}{|c|}{$\begin{array}{c}\text { Release kinetics of } \\
\text { neomycin in } 15 \% \text { ghee } \\
\text { cream }\end{array}$} & \multicolumn{3}{|c|}{$\begin{array}{c}\text { Release kinetics of } \\
\text { neomycin in } 20 \% \text { ghee } \\
\text { cream }\end{array}$} & \multicolumn{3}{|c|}{$\begin{array}{c}\text { Release kinetics of } \\
\text { neomycin in } 25 \% \text { ghee } \\
\text { cream }\end{array}$} \\
\hline 0 & 0 & 5000 & 3.69 & 0 & 5000 & 3.69 & 0 & 5000 & 3.69 \\
\hline 15 & 562.25 & 443 & 3.647 & 705.0 & 429 & 3.63 & 847.8 & & 3.618 \\
\hline 30 & 908.17 & 4091.83 & 3.619 & 1159.78 & 3840.22 & 3.58 & 1340 & 3660 & 3.563 \\
\hline 45 & 1213.52 & 3786.48 & 3.578 & 1405.65 & 3594.35 & 3.55 & 1659.41 & 3340.59 & 3523 \\
\hline 60 & 148 & 351 & 3.545 & 1663. & 3336 & 3.52 & 2036 & & 3.471 \\
\hline 75 & 1700.5 & 3299.5 & 3.518 & 1896.92 & 3103.08 & 3.491 & 2381.19 & 2618.81 & 3.418 \\
\hline 90 & 1800.68 & 3199.32 & 3.505 & 2115.33 & 2884.67 & 3.46 & 2694.53 & 2305.47 & 3.362 \\
\hline 105 & 1999.99 & 300 & 3.478 & 2282.55 & 2717.45 & 3.434 & 2948.85 & 15 & 3.311 \\
\hline 120 & 2183.48 & 2816.52 & 3.449 & 2469.33 & 2530.67 & 3.403 & 3187.82 & 1812.18 & 3.258 \\
\hline 135 & 2342.2 & 2657.8 & 3.42 & 2711.59 & 2288.41 & 3.359 & 3333.82 & 1666.18 & 3.205 \\
\hline 150 & 2493.61 & 2506.39 & 3.399 & 2876.1 & 2123.9 & 3.322 & 3583.89 & 1416.11 & 3.151 \\
\hline 165 & 2646.51 & 2353.49 & 3.371 & 3042.21 & 1957.79 & 3.291 & 3766.85 & 1233.15 & 3.091 \\
\hline 180 & 2791.99 & 2208.01 & 3.34 & 3290.25 & 1709.75 & 3.232 & 3942.6 & 1057.4 & 3.024 \\
\hline 195 & 2938.86 & 2061.14 & 3.314 & 3469.47 & \begin{tabular}{|l|l}
1530.53 \\
\end{tabular} & 3.184 & 4119.96 & 880.04 & 2.944 \\
\hline 210 & 3078.17 & 1921.83 & 3.28 & 3632.54 & 1367.46 & 3.135 & 4289.999 & 710.001 & 2.888 \\
\hline 225 & 3218.2 & 1781.8 & 3.25 & 3788.2 & 1211.8 & 3.083 & 4452.648 & 547.352 & 2.73 \\
\hline 240 & 3351.8 & 1648.2 & 3.217 & 3927.39 & 1072.61 & 3.03 & 4627.047 & 372.953 & 2.57 \\
\hline$t_{1 / 2}$ & \multicolumn{3}{|c|}{$160.86 \mathrm{~min}$ Or $2.68 \mathrm{hr}$} & \multicolumn{3}{|c|}{$116.47 \mathrm{~min}$ Or $1.94 \mathrm{hr}$} & \multicolumn{3}{|c|}{$72 \mathrm{~min}$ or $1.2 \mathrm{hr}$} \\
\hline
\end{tabular}

